\title{
THE RECEPTION OF THE FAREWELL
}

I F the Worshipful Company of the Stationers of London had compiled a list of best-selling works of fiction after 158r, Rich's Farewell would unquestionably have appeared on it. The signs that his stories enjoyed long and great popularity are various and unmistakable. By setting Rich's folk upon the stage again and again, the authors of the plays just dealt with paid the Faremell the sincerest of compliments, and at the same time provided the clearest of indications that it was attractive to Elizabethans and Jacobeans.

Ordinary readers were apparently as devoted to Rich's folk as were the playwrights-sufficiently devoted, that is, to read out of existence all but (I) a single copy of the first edition, $158 \mathrm{I}$, which may have survived in fine condition only because it reposed (unread, one suspects) for who knows how many years in the austere library of Thomas Tanner (1674-1734), bishop of St. Asaph, from whom it went directly to the Bodleian Library; (2) two imperfect copies of the second edition, I 583, both of which narrowly escaped being read to pieces, having been handled until what is left of them is ragged, tattered, and torn; (3) a single imperfect copy of the third edition, I 594, which may owe its survival partly to the stout neighbor it is stalwartly bound with; and (4) two copies of the fourth edition, I606. The dates show that the demand for the book was spirited enough to exhaust the first edition in two years and long-lived enough to justify a fourth edition twenty-five years after the first. It is no wonder that, as one bibliographer observes, Rich "appears to have been the favourite author" of Robert Walley, the lucky publisher of the first two editions. ${ }^{\mathrm{I}}$

In the sixteenth century crowned heads joined commoners in reading the works of Walley's favorite. "Your Souldiour," wrote Rich in dedicating to Elizabeth $A$ Path-way to Military Practise (1587), "hauing receiued so manie gratious wordes for other of his writinges, the which it hath pleased your Maiesty so fauorably to vouchsafe, is ... incouraged, now once againe to betake him to his Penne." Of the "other of his writinges" the Farewell was the most celebrated and far likelier

'T. F. Dibdin, Typographical Antiquities (London, 1819), IV, 279. 
liv

\section{INTRODUCTION}

to have inclined Her Majesty to graciousness than, say, the nearly interminable two parts of Rich's Don Simonides ( 1581 I, I 584).

If her "gratious wordes" could be recovered, it would be amusing to contrast them with the blast Rich's collection provoked from James VI of Scotland. Rich's masterpiece, it seems, was also known-too well known-in royal circles in Edinburgh. With one of the most charming sections in the book (which he knew in the third edition) the King was "not well pleased"; in fact, he was so much displeased that on June I8, 1595, the English diplomatic attaché in Edinburgh nervously relayed the royal reaction to London. ${ }^{I}$ To King James himself, then, the Faremell can scarcely be said to have been pleasing. Yet the very fact that it had somehow made its way to Scotland and there swum into the monarch's ken is, I suppose, a tribute to its vitality. Besides, who can be sure that other readers in Edinburgh did not share the English public's opinion of the tales rather than James's? At least one Scot was so enthralled with them that he rifled them and turned his loot into a comedy. ${ }^{2}$

Rich even earned honorable mention from an Elizabethan critic who could be as dour as King James. In Pierces Supererogation (1 593) Gabriel Harvey surrounds the author of the Faremell with highly reputable company and, indeed, allows him to lead the trio apparently intended to represent the fine art of fiction-writing in England:

Our late writers are, as they are: and albeit they will not suffer me to ballance them with the honorable Autors of the Romanes, Grecians, and Hebrues, yet I will craue no pardon of the highest, to do the simplest no wrong. In Grafton, Holinshed, and Stowe; in Heywood, Tusser, and Gowge; in Gascoigne, Churchyarde, and Floide; in Ritch, Whetstone, and Munday; in Stanyhurst, Fraunce, and Watson; in Kiffin, Warner, and Daniell; in an hundred such vulgar writers, many things are commendable, diuers things notable, some things excellent. ${ }^{3}$

\section{Praise from Caesar.}

By far the most entertaining evidence that the Farewell enjoyed wide renown is to be found in contemporary quotations of a certain phrase from Rich's prefatory section addressed "To the right courteous gentle-

${ }^{I}$ See below, p. lxxi.

${ }^{2}$ See above, pp. xl-xliii.

${ }^{3}$ The Works of Gabriel Harcey, ed. A. B. Grosart (London, 1884), II, 290. 


\section{THE RECEPTION OF THE Faremell}

women, bothe of Englande and Irelande." After teasing the ladies unmercifully, Rich concludes with the saucy and ambiguous remark, "And thus (gentlewomen) wishyng to you all, what your selues doe beste like of," and signs himself, with a mock solemnity worthy of Falstaff, "Yours in the waie of honestie Barnabe Riche" (8. I3 f.). Since honesty often meant chastity to Elizabethans, the phrase doubtless afforded Rich's contemporaries considerable merriment on semantic grounds alone. In the first quotation of it I have been able to discover, however, the merry is mixed with the sinister.

The source of that quote was one Michael Moody, who involved himself in the Stafford-Des Trappes plot of 1586 to assassinate the Queen, served as an informer probably responsible to Sir Francis Walsingham and after his death to Sir Thomas Heneage, and engaged in intrigues so complicated that "as Government agent [he] was despatching information to [Robert] Poley on the one side, and as pseudoconspirator was sending pro-recusant intelligence to James Typpinge on the other: by the very same despatches!"I

Despite his deviousness, in the communications which he sent out from the shadowy world of the secret service a far from grim humor shines. In one bit of cryptic information to Sir Thomas Heneage he took leave of the vice-chamberlain with what appears to be a snatch from a celebrated song (and with a flippancy) that may have failed to amuse that dignitary: "Vale, 20 of the merry month of May, I 595."2 While being examined on January I I, 1586, by Sir Christopher Hatton about his part in the Stafford-Des Trappes plot, he revealed a code devised by himself and a fellow-spy: "He sayeth, about the Tyme of his comynge out of France, it was agreed between him and Lyllye, that in such Letters conteyning any Secrets, which passed between them, this Examinat should be named Quinty, and Lillye to be named Ascham."3 At this revelation how could his examiners have forborne to smile?

What could be expected next of an intelligencer who quoted a popular lyric to the vice-chamberlain and wrested the venerable names of two great rhetoricians (Quinty presumably being an irreverent

'Ethel Seaton, "Marlowe, Poley, and the Tippings," RES, V (1929), 282.

${ }^{2}$ HMC, Salisbury MSS, V, 214. Compare Nicholas Breton's "In the merry month os May."

${ }^{3}$ A Collection of State Papers Left by ... Lord Burghley, ed. W. Murdin (London, 1759), p. 578 . 
lvi

\section{INTRODUCTION}

abbreviation of Quintilian) into such contexts? Next, as a matter of fact, it was Rich's turn to serve as an alias. Witness the testimony in April (?), I59I, of one Robert Rutkin, who probably "served as what in modern espionage is known as a 'letter-box,' or 'cover address,' receiving and forwarding reports from the spy [Moody] and instructions to him": ${ }^{1}$

Robert Rutkin broker saieth that the party who wrote the lettres vnto him by the name of Bar[naby] Riche is Michaell Moody who liveth either at Brussels or Antwerpe.... The said Rutkin saieth that his neighboure mencioned in the lettere is one Robt Poolye and that he deliuereth him letteres for Sir Thomas Henneage \& sendeth letters to him from Sir Thomas Henneage. Sometime hee [Moody] writeth as hee doeth now (yours in the waye of honestie qd Bar Riche) but most commonly he writeth M. M. ${ }^{2}$

The correspondents of Moody-Quinty-Rich-M. M. were fortunate to be plied not only with the latest intelligence from abroad but also with aliases drawn from the world of letters and learning and with quotations of a popular song and Riche His Farewell to Militarie Profession.

The first to notice Rich's famous phrase in print, so far as I know, was Thomas Nashe, never one to overlook a chance to generate mirth, innocent or not, at the expense of a fellow-author. In dedicating Have with You to Saffron-Walden (1596) to Richard Lichfield, the Cambridge barber, he writes, "A rich spirit, quoth a ? nay then, a spirit in the way of honestie too: loe, this is to bee read in nothing but in Barnabe Riches workes. Spend but a quarter so much time in mumping vppon Gabrielisme [as you have spent on Rich's works?], and Ile be bound ... thou wilt not anie longer sneakingly come forth with a rich spirit."3 Miraculous Barnaby, to receive (more or less) honorable mention from both Master Nashe and Dr. Harvey.

The author of the comedy The Weakest Goeth to the Wall (1600) also did Rich honor by borrowing the plot of the first story in the Farewell for his play, by naming one of his characters Barnaby, apparently after

I John Bakeless, The Tragicall History of Christopher Marlowe (Cambridge, Mass., 1942), I, 178.

${ }^{2}$ For the transcriptions of these excerpts (PRO, State Papers Domestic 12/238/140/ fol. 27 I), I am obliged to Leslie Hotson. Other parts of Rutkin's deposition are quoted by F. S. Boas, Christopher Marlowe (Oxford, 1940), p. 267, and Bakeless, I, 178. Note that the recorder of the deposition duly enclosed the quotation from the Faremell in parentheses, the Elizabethan equivalent of quotation marks.

${ }^{3}$ The Works of Thomas Nashe, ed. R. B. McKerrow (London, 1904), III, $16 \mathrm{f}$. 


\section{THE RECEPTION OF THE Faremell}

the author of his source, and by broadcasting Rich's famous valedictory from the stage. ${ }^{1}$ Hoping to remain incognito, the hero of the drama, Duke Lodowick, offers a bribe to Barnaby Bunch, a tailor who provides most of the low comedy in the piece, to keep his identity a secret. In reply Barnaby refuses to exact a price for his silence and magnanimously proposes himself as a servant to the impoverished duke and his family: "Ye shall commaund me to serue you, your wife, and your daughter in the way of honestie, like honest Barnabie."2 This bit of whimsy may have been the playwright's quaint way of acknowledging his debt to Rich. But did the dramatist also expect his audience to recognize the phrase and be excited to laughter by the fillip at honest Barnaby? One presumes so. Otherwise Bunch's speech would have struck his hearers as being meaningless patter.

It is possible that Shakespeare also paid his respects to honest Rich in much the same way as the author of The Weakest Goeth to the Wall. One scholar has recently advanced convincing arguments that the fifth story in the Faremell is a source of The Merry Wives of Windsor. ${ }^{3}$ In the light of these arguments two passages in the comedy merit special scrutiny. In one speech which has never been satisfactorily glossed Shakespeare may allude to the fanciful title of a book by Rich, as we have already observed. ${ }^{4}$ In the other, a far subtler comic character than Barnaby Bunch repeats the very words of Rich's valediction to the ladies of England and Ireland: prattling, malapropizing, and making ten words do the work of two as is her wont, Mistress Quickly says, "I had myself twenty angels given me this morning; but I defy all angels (in any such sort, as they say) but in the way of honesty" (II. ii. 72-75). And so Rich may deserve to take his place in the illustrious company of my old lad of the castle and Cousin Garmombles.

However one may choose to explain Mistress Quickly's babbling of the phrase, its use in Moody's dispatches before April (?), 1591, in Nashe's Have with You (1596), and in The Weakest (1600), suggests that it was more or less celebrated for at least a decade and breeds the suspicion that there are still other quotations of it not yet detected. That Rich remained ignorant of the celebrity which his words gained is most

I For the relationship of the comedy and the tale see above, pp. xxxviii $f$.

${ }^{2}$ The Weakest, ed. Sir Walter Greg, Malone Society Reprints (Oxford, 1912), lines $499 \mathrm{f}$. And see the note on $4.15 \mathrm{f}$.

${ }^{3}$ See above, pp. xlviii-l.

${ }^{4}$ See above, p. xlix. 
lviii

\section{INTRODUCTION}

doubtful. "Yours in the way of honesty" probably had something to do with the title of another of his best-sellers, The Honestie of This Age (1614, 1615, 1616), and certainly had a great deal to do with a remark in Faultes Faults, and Nothing Else but Faultes (I606), where Rich says (sig. C.2v), tongue in cheek, "This olde protestation, Yours, in the way of honestie, is little cared for: euerie Gull was woont to haue it at his tongues end, but now it is forgotten." Honest Barnaby was too pessimistic.

Long after every gull had ceased to quote the old protestation, the sort of humor which it represents and which pervades the Faremell attracted admirers of whom Rich could never have dreamed. After reading through such Elizabethan novels as Euphues and the Arcadia, not to mention H. C.'s The Forrest of Fancy and John Grange's The Golden Aphroditis, modern critics habitually fall with glad cries upon Rich's stories. A few samples of the critical rhapsodies will suffice.

One editor pronounces the Faremell "a landmark in Elizabethan short-story writing" and reprints Rich's second tale "on its merits, which are great. ... The story is delightful in its circumstantial romantic incidents, and the characterization of Silla is charming in its psychological realism." He concludes: "Rich's contributions to the Elizabethan short story are romantic charm, gaiety and lightness of touch, good vivid dialogue, directness and ease."I

Though one may be unable to agree entirely with another critic who believes it to be "plain that the author's sole interest lies in the telling of his stories with as few external embellishments or encumbrances as possible," it is nevertheless gratifying to learn that, in the opinion of an authority on Continental as well as English fiction, "Few works of the English Renaissance show to the same extent [as the Farewell] the reserve and detachment characteristic of the Italian novellieri."

The author of a history of the short story in English apparently considers no praise too high for "merry Barnabe Riche" and his Farewell, "one of the pleasantest story-books of the period." Rich's narrative, he asserts, is

neither burdened with digressions, as with Whetstone and Gascoigne, nor

' Elizabethan Tales, ed. E. J. O'Brien (London, 1937), pp. 23 f. For a Victorian critic's dissenting opinion of "Apolonius and Silla" see above, p. xlvii.

${ }^{2}$ René Pruvost Matteo Bandello and Elizabethan Fiction (Paris, 1937), p. 110. 


\section{THE RECEPTION OF THE Faremell}

overfraught, as in Fenton, with warning tragedies. The humor is of the gayest ... and he comes to the charge merrily, with a constant rallying and a bantering flattery.... There is a suggestion of Chaucer about him, and not a little of the poet's merry humor appears in certain fabliau-like stories of this collection, while the comparative infrequency of oratorical love-speeches, the rapidity of movement, good dialogue and monologue, give an impression of ease and lightness wanting in most of the serious "histories" [by Gascoigne, Painter, Fenton, and Whetstone]... .

The stories themselves are diverse in character. . . . Some are condensed romances, . . . others admirably compact novelle . . . and all are primed with the spirit of the renaissance. . . . [Their] variegated narrative is carried on with much of the color and realistic detail of the later comedy, and shows what an Englishman could do when he was trying to be neither preacher, nor grand stylist. Read ... "Of two brethren and their wives" ... and see how much lively humor and true observation, and how little affectation is to be found there.

Indeed, under Riche's lighter fingering, some of the renaissance peculiarities of narrative lose their odious qualities. A lengthy declamation is not unpalatable when sauced with wit ... and a long declaration of love not tedious if humorous as well. "You might do much," we feel like saying [to Rich] with Olivia, in the play whose plot was one of his own stories."

More encomiums could be cited to show that other present-day readers have found as much delight in the Farewell as the Elizabethans, and for much the same reasons. The sixteenth century, the twentieth century: other times, other manners-but happily the same tastes, so far as Rich's stories are concerned. It is time, however, that each reader be invited to peruse the tales and validate or reject the judgments of critics ancient and modern for himself. The Faremell is his to use, though only, of course, in the way of honesty.

${ }^{1}$ H. S. Canby, The Short Story in English (New York, 1932), pp. 127-29. 